\title{
磁場下過冷却凍結保存法のための凍結槽一体型磁場印加用コイルの開発
}

\section{Development of a Magnetic Field Generating Coil Combined with the Cooling Bath for Supercooled Freezing under the Magnetic Field}

\author{
須永康太郎 (学生会員), 桑名健太(正会員), 土肥健純(正会員) \\ Kotaro Sunaga, Kenta Kuwana and Takeyoshi Dohi
}

\begin{abstract}
In this paper, we developed a magnetic field generating coil for finding out an effective magnetic field for supercooled freezing of biological tissues under the magnetic field. The range of the frequency and the magnetic flux density of the inducing magnetic field was expanded by reducing the resistance compared with the previous coil. The upper range of the frequency increased from $2 \mathrm{kHz}$ to $10 \mathrm{kHz}$ and that of the magnetic flux density increased from $0.3 \mathrm{mT}$ to $2.0 \mathrm{mT}$. We evaluated the magnetic field dependency of the degree of supercooling of the porcine ovarian tissues using the developed coil. In supercooled freezing, it is reported that the growth of the ice crystals, which is a cause of cell destruction, was suppressed with the increase of the degree of supercooling. This result indicates that increasing the degree of supercooling may enable to prevent cell destruction. Therefore we evaluated the effect of the magnetic field by measuring the degree of supercooling. As a result of the measurement, the averages of the degree of supercooling at $10 \mathrm{kHz}$ frequency of $2.0 \mathrm{mT}$ magnetic field increased the most from $9.1 \pm 1.7^{\circ} \mathrm{C}$ for without magnetic field to $10.5 \pm 1.7^{\circ} \mathrm{C}$.
\end{abstract}

Key Words

Organ Preservation, Coil, Supercooling, Magnetic Field

\section{1. 背景-目的}

小児がんは化学療法や放射線療法の発達により全体の 7 割が 治癒可能となっているが, これらの治療法は副作用として生殖機 能の低下・喪失をもたらす.これに対して, 治療前に血管付精巣・ 血管付卵巣を取り出して凍結保存し, 治療後に移植することで妊 孕性を温存する方法が提案され，移植技術の開発が進められて いる ${ }^{1,2}$. この方法の実現には, 血管付精巣・血管付卵巣を凍結 保存する技術が必要である. 成人に対しては精子や卵子, 受精 卵・胚の凍結保存があるが, 思春期前の小児に対しては適用寸 ることができず 1,2$)$, 血管付精巣・血管付卵巣を凍結保存する技術 の開発が求められる.

2015 年 11 月 11 日受付

2016 年 2 月 5 日掲載決定

東京電機大学

干120-8551 東京都足立区千住旭町 5

Tokyo Denki University

5 Senjuasahi-cho, Adachi-ku, Tokyo 120-8551, Japan
生体組織の凍結では, 細胞内外での氷晶の成長による細胞膜 の破壊が問題となる ${ }^{3)}$. 生体組織の凍結法として, 現在は緩慢凍 結法 4-6)とガラス化法 7-10)が用いられているが, 複雑な組織に対し てはガラス化法が適切と報告されている ${ }^{11)}$. ガラス化法は, 細胞 を高濃度の凍結保護剤に浸漬し, 液体窒素で急速に冷却するこ とで, 水分を結晶化させずにガラス化状態で涷結する方法である. この手法においては対象全体に凍結保護剤を浸透させる必要が あるが, 厚みのある組織に対しては全体に凍結保護剤を浸透さ せられず 10), 血管付精巣・血管付卵巣に対しては適用できない.

これに対しわれわれは, 過冷却凍結に着目し, 研究を行ってき た ${ }^{12-14)}$. 過冷却凍結は, 過冷却現象を利用して対象全体を瞬時 に凍結する方法である. Fig.1 に過冷却凍結時の温度変化を示 す. 対象を泠却していくと, 液体が凝固点以下の温度になっても 液体の状態を保つ過冷却状態になる. その後, 過冷却状態が偶 発的に解消し, 急激な温度上昇を伴って瞬時に凍結する.この 凍結を過冷却凍結という. 過冷却凍結においては, 過冷却解消 時に温度が凝固点まで上昇し, 凝固点と過冷却解消直前の温度 との差は過冷度と呼ばれる. $30 \times 30 \times 20 \mathrm{~mm}$ の充填絹豆腐の過 冷却凍結において, 過冷度が大きいほど氷晶が微細化し, 細胞 


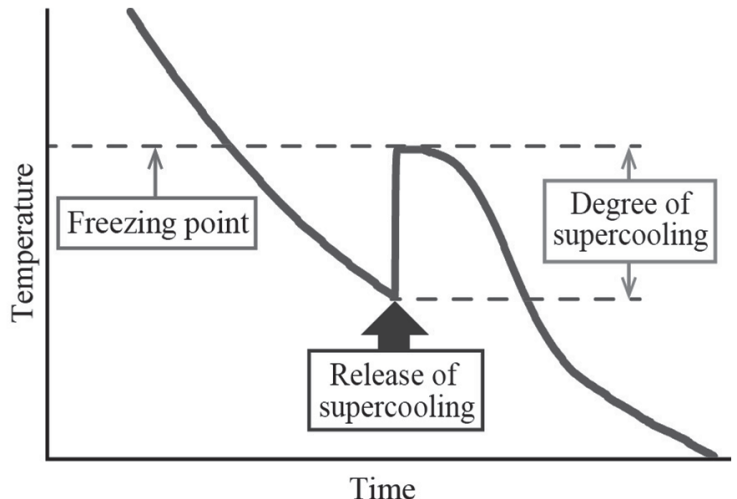

Fig.1 Time response of temperature during supercooled freezing

破壊と関連のあるドリップ量も減少することが報告されている ${ }^{15)}$. 細胞においても同様に, 過冷度の増加に伴う水晶の微小化によ り細胞破壊が抑制されると予想される. そこでわれわれは過冷度 の増加に着目して研究し, 原理は明らかになっていないものの交 流磁場を印加することで過冷度が増加することを実験的に確 認した ${ }^{16)}$

そこで本研究では, 生体組織の過冷度の磁場周波数・磁束密 度依存性を評価するために, 磁束密度範囲の拡大に向けて, 発 熱を低減したコイルを開発する.また, 開発したコイルを用いて磁 場下過冷却凍結における生体組織の過冷度を計測し, 過冷度の 磁場周波数・磁束密度依存性を評価する.

\section{2. 磁束密度範囲の拡大に向けたコイルの発熱低減の方法}

磁束密度範囲の拡大に向けて, コイルの発熱を低減する方法 について考える.

コイルの発熱量は電力に依存し, 発熱量を低減するためには コイルの電力を低減する必要がある. 電力には熱や動力として消 費される有効電力と, 励磁電流や回転磁界を作る無効電力の 2 種類の電力がある ${ }^{17)}$. 本研究ではコイルの発熱に重点を置き, 有 効電力の低減を行う.

有効電力 $P_{e}$ は抵抗 $R$ と電流の実効值 $I_{\mathrm{rms}}$ を用いて次の式で 表される ${ }^{18)}$.

$$
P_{e}=R I_{\mathrm{rms}}^{2}
$$

式(1)から抵抗 $R$ または電流の実効值 $I_{\mathrm{rms}}$ を下げることで有効 電力を低減できると考えられる. 一方で, コイルによって発生する コイル内部の磁束密度 $B$ は, 真空透磁率 $\mu_{0}$, 電流 $I$, 単位長さ当 たりの巻数 $n$ を用いて次の式で表される.

$$
B=\mu_{0} I n
$$

式(2)から電流を下げると磁束密度が減少するので, 磁束密度 範囲の拡大という目的に反寸る. そこで本研究ではコイルの抵抗 を低減することにより有効電力を低減する.

コイルの抵抗 $R$ は抵抗率 $\rho$, 導線長さ $l$, 導体断面積 $S$ を用い て次の式で表される.

$$
R=\rho \frac{l}{S}
$$

式(3)から導線長さの短縮と導体断面積の増加によって抵抗を 低減できることがわかる.

\section{3. 凍結槽一体型磁場印加用コイルの設計·試作}

前述の方法に沿ってコイルの設計・試作を行う。

磁場印加用コイルの要求仕様は次のように定めた.

(1)血管付精巣・血管付卵巣を凍結可能なサイズの凍結槽を格納 可能

(2) $2.0 \mathrm{mT}$ 発生時にも冷却効率を維持可能

Fig.2(a)に従来コイルの構成を示す. 従来コイルでは, 抵抗に 影響する導線長さや導体断面積について考慮した設計がされて いなかった. そのため, 従来コイル使用時は磁束密度が $0.3 \mathrm{mT}$ を超えると凍結対象の冷却効率が低下した. 新コイルでは要求仕 様を満たす範囲内でできるだけ抵抗を小さくするために, 導線長 さを短縮し, 導体断面積を拡大寸る方針で設計を行った.

\section{1 導線長さの課題に対する設計}

従来コイルはコイル長さが長いため巻数が多かった. また, 従 来コイルは断熱材が巻かれた凍結槽を囲うように設置されており, コイルと凍結槽との間に断熱材と芯材が存在することでコイル径 が大きかった.さらに電源装置への接続ケーブルとして長さ $2 \mathrm{~m}$ のケーブルを使用していた. これらは全て, 抵抗増加の因子の 1 つである導線長さの増大に繋がっていた. そこで, 新コイルでは コイル導線長さの短縮に向けて巻数の低減とコイルの細径化を 行った. Fig.2(b)に新コイルの構成を示す. 新コイルはソレノイドコ イルで構成する.ソレノイドコイル内の磁場は均一であると仮定し, 試料全体がコイル内に収まる範囲でコイル長さを短くした. また, 新コイルはコイルの細径化を実現するために, 断熱材を介さず導 線を凍結槽に直接巻きつけた. さらに, 将来的に血管付精巣・血 管付卵巣を凍結する際に十分なスペースが確保できる範囲で, コイルの芯となる凍結槽を細径化した. ただし, 凍結槽底部の径 は冷却機吸熱部の径に依存するため従来凍結槽と同じ径とした. Fig.3 に凍結槽の寸法を示す. 凍結槽の材料には従来と同じくポ リエチレンを用いた. さらに新コイルは電源装置に直接接続し,

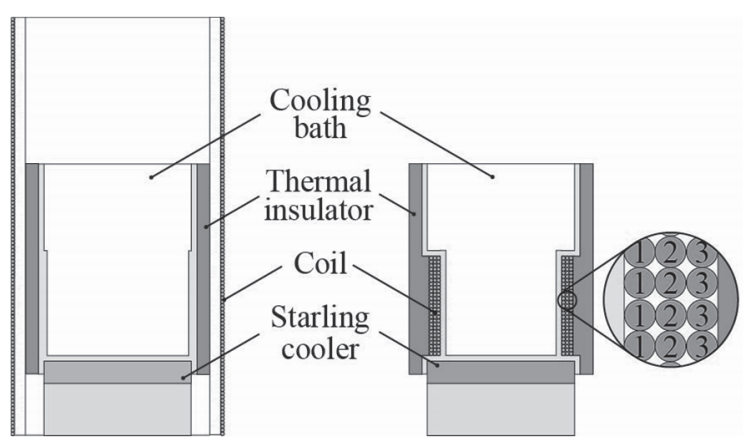

(a) Previous

(b) Proposed

Fig.2 Comparison of the coil and the cooling bath 


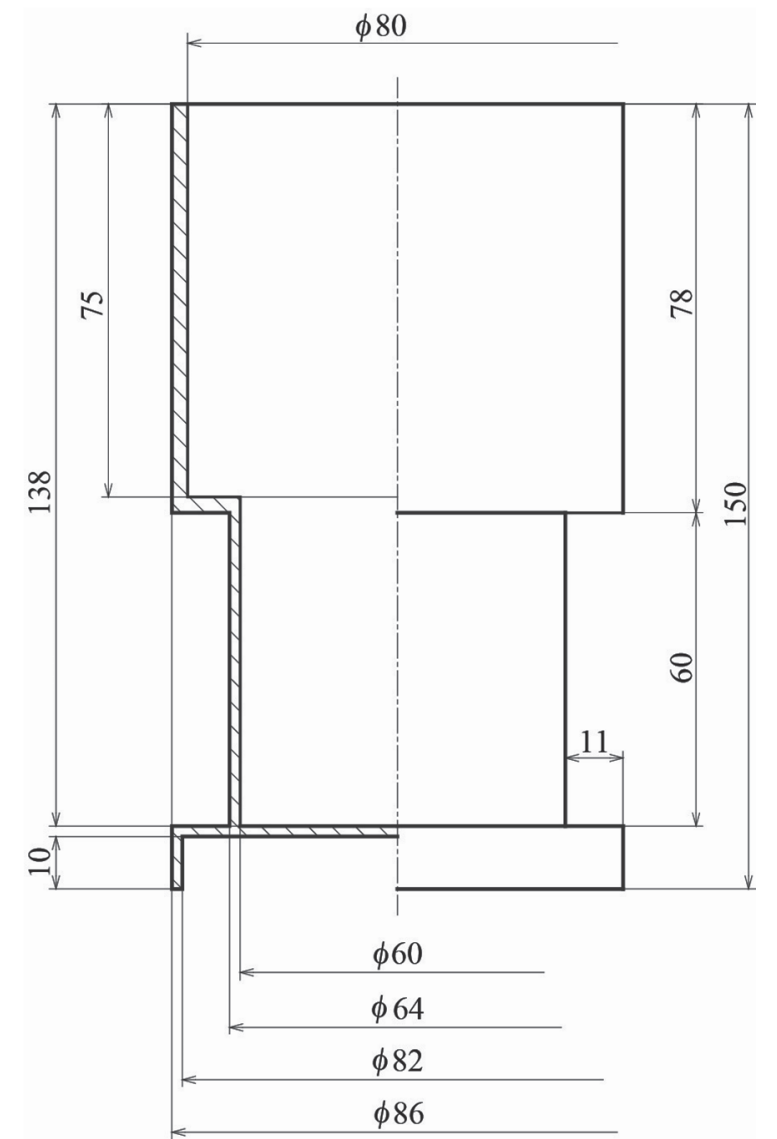

Fig.3 Dimensions of the cooling bath

\section{配線による抵抗を低減した.}

\section{2 導体断面積の課題に対する設計}

導体断面積の増加に向けて導線を変更した. 導体断面積を増 加する際には, 磁束密度に関連する単位長さ当たりの巻き数, 周 波数特性に関連する表皮深さについて考える必要がある.まず, コイルの単位長さ当たりの巻数について考える. 式(3)を変形させ て, 要求磁束密度を $B=2.0 \times 10^{-3} \mathrm{~T}$, 電流上限を $2 \mathrm{~A}$ に設定 ᄂ, 真空透磁率 $\mu_{0}=4 \pi \times 10^{-7} \mathrm{H} / \mathrm{m}$ を代入すると必要な単位長 さ当たりの巻数 $n$ は次のようになる.

$$
n \geqq \frac{B}{\mu_{0} I}=\frac{2.0 \times 10^{-3}[\mathrm{~T}]}{4 \pi \times 10^{-7}[\mathrm{H} / \mathrm{m}] \times 2[\mathrm{~A}]}=796[\text { 巻 } / \mathrm{m}]
$$

$n$ の逆数をとるとコイルの線径 $d_{0}$ が求められ次のようになる.

$$
d_{\mathrm{o}} \leqq \frac{1}{796 \times 10^{-3}[\text { 巻 } / \mathrm{mm}]}=1.26[\mathrm{~mm}]
$$

続いて表皮深さについて考える. 高周波電流においては, 電 流が導体の表面付近のみにしか流れなくなり, 実質的に断面積 が小さくなる. 表皮深さとは導体表面から電流が流れることができ る深さのことで, 周波数が高くなるほど小さくなる. 平面状導体の 場合の表皮深さ $t$ は, 透磁率 $\mu 0$, 比透磁率 $\mu$, 導体の導電率 $\sigma$, 周波数 $f$ を用いて次の式で表される.
Table 1 Skin depth of the copper wire

\begin{tabular}{c|c}
\hline \hline Frequency $[\mathrm{Hz}]$ & Skin depth $[\mathrm{mm}]$ \\
\hline 20 & 14.83 \\
\hline 200 & 4.69 \\
\hline $2 \mathrm{k}$ & 1.48 \\
\hline $20 \mathrm{k}$ & 0.47 \\
\hline $200 \mathrm{k}$ & 0.15
\end{tabular}

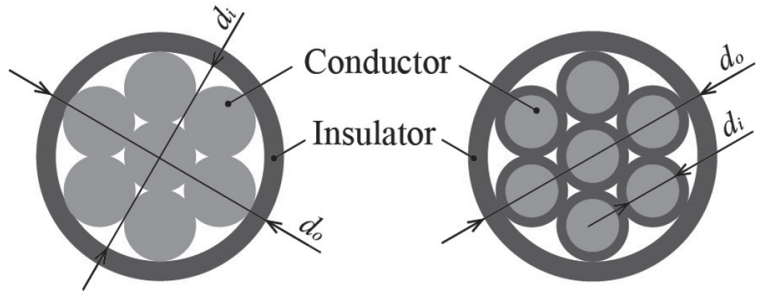

(a)Previous
Fig. 4 The cross section of the wire

$$
t=\frac{1}{\sqrt{\pi f \mu_{0} \mu \sigma}}
$$

ここで, $\mu_{0}=4 \pi \times 10^{-7} \mathrm{H} / \mathrm{m}$, 一般的な導線に用いられる銅導体 $\left(\mu=0.999991, \sigma=5.76 \times 10^{7}\left[\Omega^{-1} \cdot \mathrm{m}^{-1}\right]\right)$ を例にとり, 周波数に 対する表皮深さを計算すると Table 1 のようになる. 本研究では従 来コイルがコイルとして機能しなくなる周波数 (自己共振周波数) である $200 \mathrm{kHz}$ 以下において表皮効果が発生しないようコイルを 設計する. Table 1 から $200 \mathrm{kHz}$ 以下の周波数において表皮効果 を生じさせないためのコイル導線における導体部分の直径 $d_{\mathrm{i}}$ の 上限は次のようになる.

$$
\begin{aligned}
d_{\mathrm{i}} & =2 \times(200 \mathrm{kHz} \text { 時の表皮深さ })=2 \times 0.15[\mathrm{~mm}] \\
& =0.3[\mathrm{~mm}]
\end{aligned}
$$

式(6)と合わせて導線を選定する際の条件は次のようになる.

$$
d_{\mathrm{o}} \leqq 1.26[\mathrm{~mm}] \cap d_{\mathrm{i}} \leqq 0.3[\mathrm{~mm}]
$$

従来コイルで使用していた導線は $d_{0}=1.1 \mathrm{~mm}, d_{i}=0.5$ $\mathrm{mm}$ であり, 条件を満たさない. 導体径を細く維持しつつ導体断 面積を増加するために, 従来コイルで使用していた撚り線を, 新 コイルではリッツ線に変更する. Fig.4 に示すように, リッツ線は通 常の撚り線と異なり素線が一本毎に絶縁された構造になっており, 素線の導体径が $d_{i}$ に相当する. この構造により, 表皮効果の生じ ない導体径を維持しつつ導体断面積を増やすことが可能となる. 本研究では $d_{\mathrm{o}}=1.0 \mathrm{~mm}, d_{\mathrm{i}}=0.24 \mathrm{~mm}$ のリッツ線(古川電機 工業株式会社;TEX-ELZ 7/0.24 )を選定した. これにより導体面 積が従来の導線の $0.14 \mathrm{~mm}^{2}$ から $0.34 \mathrm{~mm}^{2}$ に増加した.

また, 断面積の増加と同じ効果をもたらす並列化についても検 討した. 新コイルは, コイルの抵抗を下げるために導線を並列接 続して重ねて巻き, コイルを 3 層にした. Fig.2(b)に新コイルの巻 き方を示す. Fig.2(b)の拡大図に示した 1, 2, 3 の断面はそれぞ れコイルの各層を表している. 


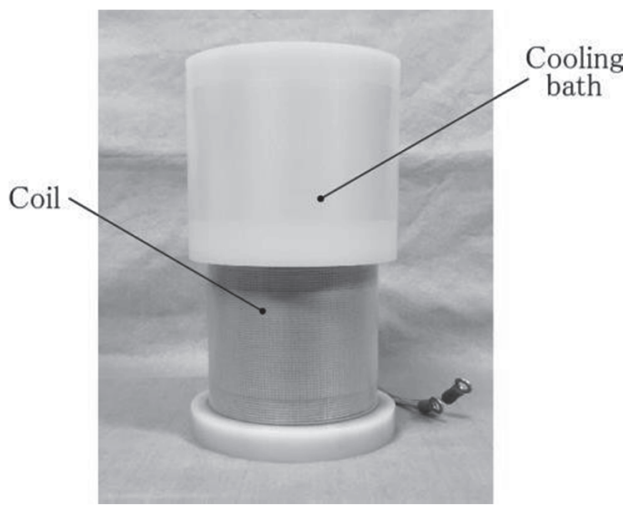

Fig.5 Coil united the cooling bath

Table 2 Characteristic of coil

\begin{tabular}{c|c|c}
\hline \hline & Previous & Proposed \\
\hline Size [mm] & H300 $\times$ D12.5 & H60 $\times$ D67 \\
\hline Wire Diameter [mm] & 1.1 & 1.0 \\
\hline Wire Turns [-] & 213 & $59 \times 3$ \\
\hline $\begin{array}{c}\text { Self-Resonant Frequency } \\
{[\mathrm{Hz}]}\end{array}$ & $200 \times 10^{3}$ & $4 \times 10^{6}$ \\
\hline
\end{tabular}

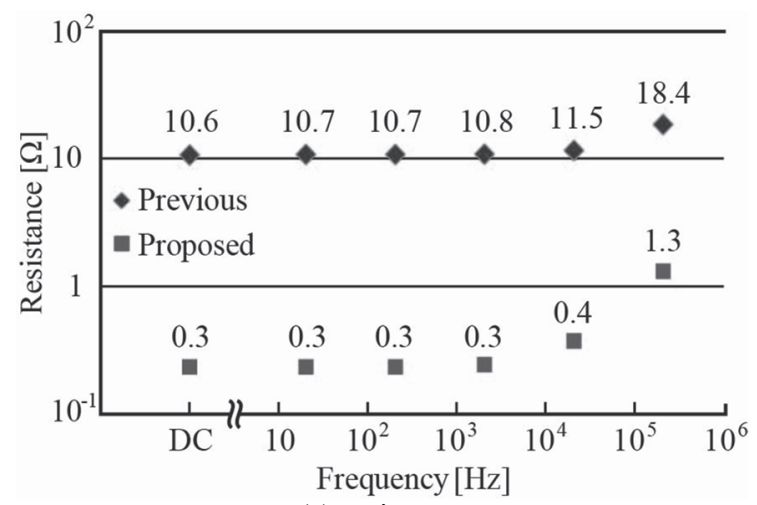

(a)Resistance

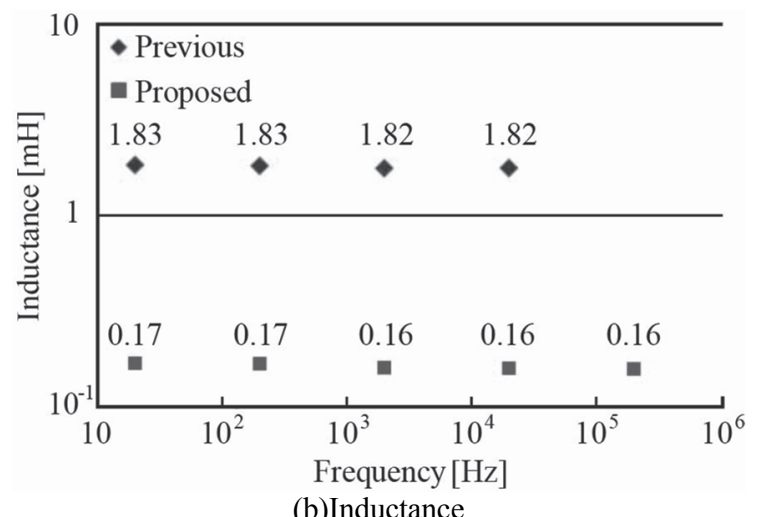

(b)Inductance

Fig.6 The relationship between the frequency and (a)the Resistance, (b)the Inductance

\section{3 凍結槽一体型磁場印加用コイルの試作}

Fig.5 に新コイル外観を示す. 磁場下過冷却凍結を行う際には, 冷却時の外気温の影響を避けるために凍結槽とコイルに断熱テ ープ (MISUMI 社; HOPET3-30-10, HOPET10-30-10)を巻く.
Table 2 にコイルの仕様を示す. 従来コイルも新コイルもピッチ 間隔が線径と同じになるよう隙間なく巻いた. Fig.6 にコイルの抵 抗とインダクタンスの周波数特性を示寸. 抵抗とインダクタンスは LCR メータ (nF 社;ZM2375) で計測した. 新コイルは全周波数に おいて抵抗を従来コイルの $8 \%$ 以下まで低減し, インダクタンスを $10 \%$ 以下まで低減した. インダクタンスが低減すると, コイルが機 能する限界の周波数である自己共振周波数が大きくなり, 結果と して新コイルの自己共振周波数は従来の $200 \mathrm{kHz}$ から $4 \mathrm{MHz}$ で拡大した。

\section{4. 凍結槽一体型磁場印加用コイルの特性評価}

発生可能な磁束密度, 同じ磁束密度を発生した際の有効電 力, 磁場下で泠媒を泠却した際の冷却速度・冷媒温度均一性を 従来コイルと新コイルで比較することで, 試作したコイルの特性を 評価した.

\section{1 発生可能な磁束密度の比較}

従来コイルと新コイルで, 発生可能な磁束密度を比較する.

一定電流を出力することが可能なバイポーラ電源 $(\mathrm{nF}$ 社; BP4610)から発生した定電流をコイルに流し, 凍結時に試料を設 置する位置の磁束密度をガウスメータ (東陽テクニカ社;410 型ガ ウスメータ)で計測した. Fig.7 に磁束密度計測セットアップの概略 図を示す. 試料の凍結槽底面からの位置は両コイルで $10 \mathrm{~mm}$ と 共通である. 凍結槽内壁からの位置は, 凍結槽の径を変更した 関係から両コイルで異なり, 従来コイルでは中心に向かって 22 $\mathrm{mm}$, 新コイルでは $10 \mathrm{~mm}$ とした. また, コイル表面の温度上昇を 計測するためコイル表面に $\mathrm{K}$ 熱電対を設置した. 磁束密度を 0 $\mathrm{mT}$ から $2.0 \mathrm{mT}$ まで $0.1 \mathrm{mT}$ 刻みで増加させた.このとき同時に 電流の実効值と磁束密度の関係を計測した. これを DC, $20 \mathrm{~Hz}$, $200 \mathrm{~Hz}, 2 \mathrm{kHz}, 10 \mathrm{kHz}$ の 種類の周波数で行った.

磁場を発生した結果, 従来コイルでは発生した磁束密度が 1.0 $\mathrm{mT}$ を超えるとコイルの温度が $50{ }^{\circ} \mathrm{C}$ を超えたため, 過冷却凍結 には不適切と判断し, 従来コイルは $1.0 \mathrm{mT}$ が最大磁束密度と判 断した. また $0 \sim 120 \mathrm{~V}_{\mathrm{p}-\mathrm{p}}$ の電圧範囲において, 従来コイルは 2 $\mathrm{kHz}$ で $0.8 \mathrm{mT}$ までの磁場しか発生できなかった. また $10 \mathrm{kHz} て ゙$ は $0.1 \mathrm{mT}$ 以上の磁場を発生できなかった. 新コイルについては, 全ての周波数で $2.0 \mathrm{mT}$ まで磁場を発生させることができた. Fig.8 に同じ磁束密度を発生させた際の電流の実効值を示す. DC 時, $20 \mathrm{~Hz}, 200 \mathrm{~Hz}, 2 \mathrm{kHz}$ 時の全てで, 新コイルは全ての磁束密度に おいて従来コイルよりも小さい電流で同じ磁束密度の磁場を発生 させることができた。

新コイルが従来コイルよりも大きな磁束密度を発生できたのは, インダクタンスの低減により周波数の増加に伴うインピーダンスの 増加を抑え，電流が流れや寸くなったからであると考えられる.ま た, 式(2)を見ると, 単位長さあたりの巻数が増加すると同じ磁束 密度を発生させるために必要な電流が小さくなることがわかる.こ の式の通り, 単位長さあたりの巻数が増えた新コイルでは同じ磁 束密度を発生させるために必要な電流が小さくなることが確認で きた.

以上の結果より, 新コイルは発生可能な磁束密度の上限が従 


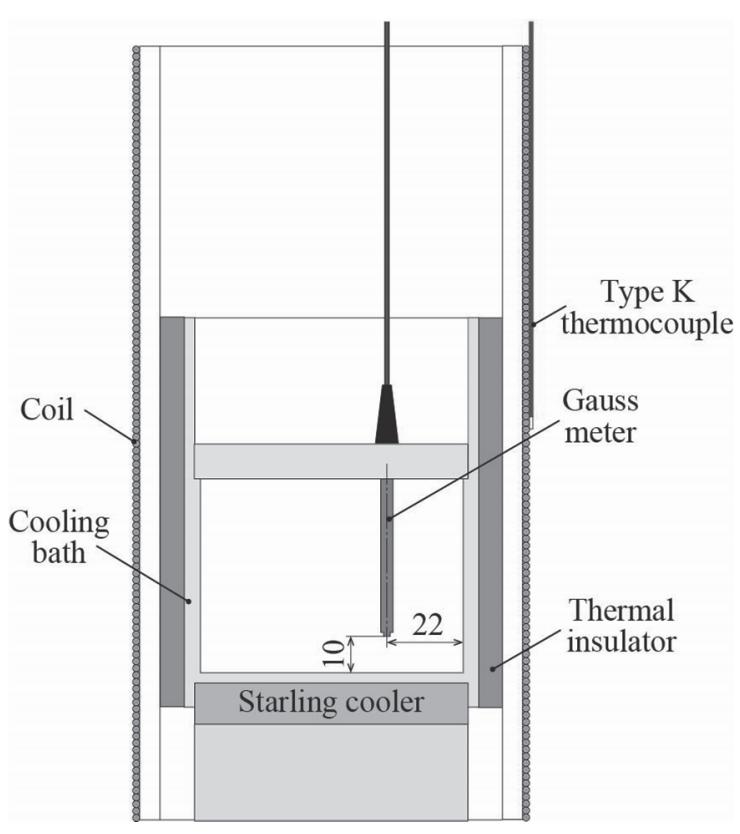

(a)Previous

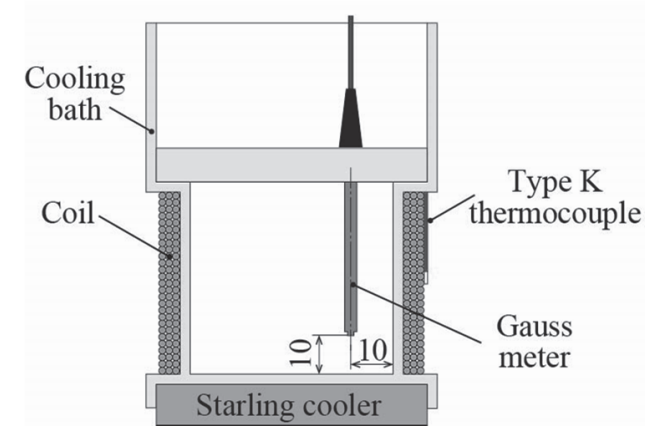

(b)Proposed

Fig.7 Measurement setup of the magnetic flux density

来の $0.3 \mathrm{mT}$ から $2.0 \mathrm{mT}$ まで拡大し, 磁場周波数の上限が従来 の $2 \mathrm{kHz}$ から $10 \mathrm{kHz}$ まで拡大した.

\section{2 磁場を発生した際の有効電力の比較}

同じ磁束密度を発生した際の有効電力を, 従来コイルと新コイ ルで比較した。

式(1)から, 同じ磁束密度を発生した際の電流の実効值と抵抗 が分かれば, その際の有効電力を求めることができる. 4.1 で計測 した電流の実効值と, 事前に計測した抵抗值を用いて, 有効電 力を算出した.

Fig.9 に同じ磁束密度の磁場を発生した際の有効電力を示す. 新コイルは全ての周波数において, 従来コイルに比べて磁束密 度の増加に伴う有効電力の増加を抑えた. Table 3 に全周波数に おける低減率を示す. 新コイルは, DC から $2 \mathrm{kHz}$ の全ての周波 数で従来コイルに比べて発熱の指標となる有効電力が $97 \%$ 以上 低減した. Fig.10に新コイルにおける磁場周波数と有効電力の関 係を示す. 磁場周波数の増加に伴い新コイルの有効電力は増加 したものの $3 \mathrm{~W}$ 未満に抑えられた. 従来コイルでは $0.5 \mathrm{mT}$ 未満 の磁束密度発生時に $3 \mathrm{~W}$ に達したことから, 新コイルでは広い磁 束密度範囲で有効電力を抑えられることがわかる.

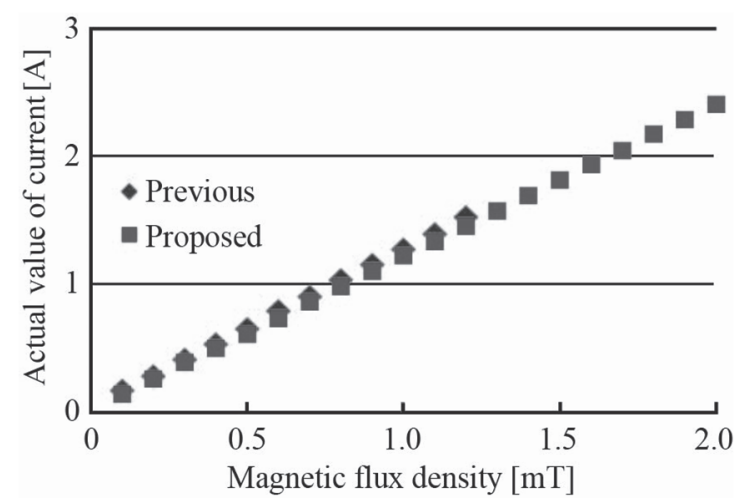

(a) DC

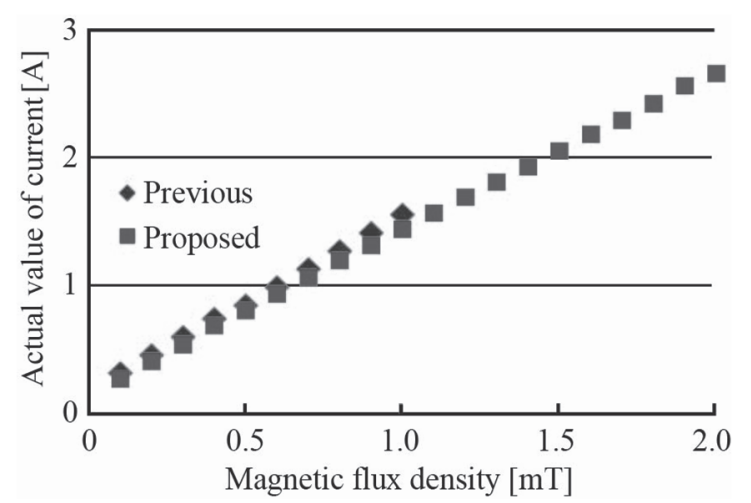

(b) $20 \mathrm{~Hz}$

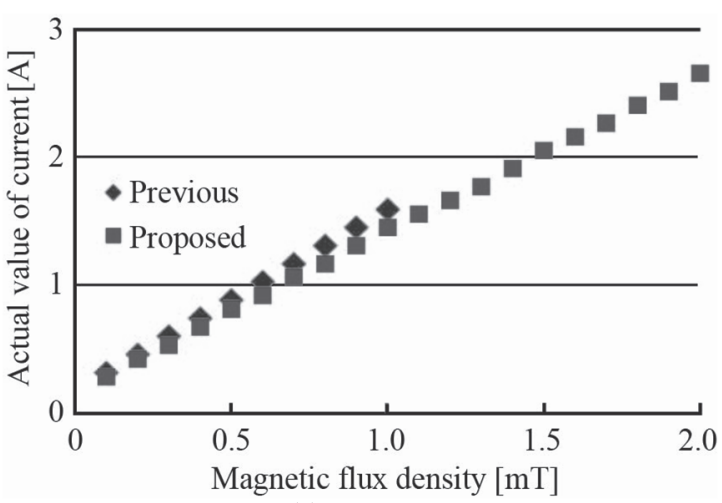

(c) $200 \mathrm{~Hz}$

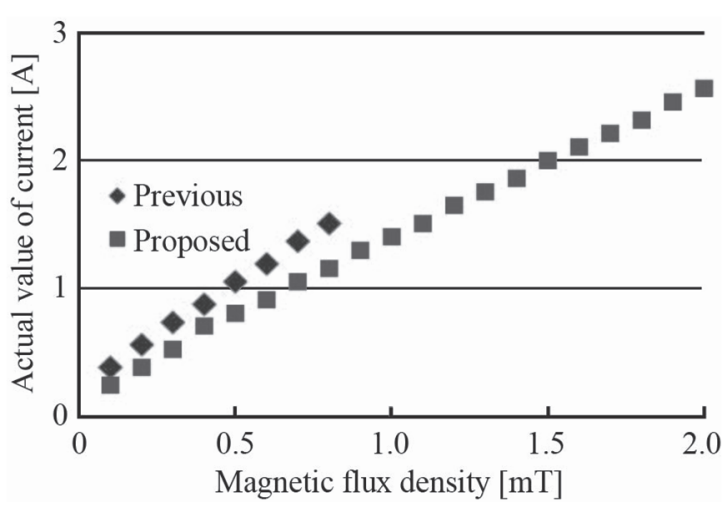

(d) $2 \mathrm{kHz}$

Fig. 8 The relationship between the magnetic flux density and the actual value of current 


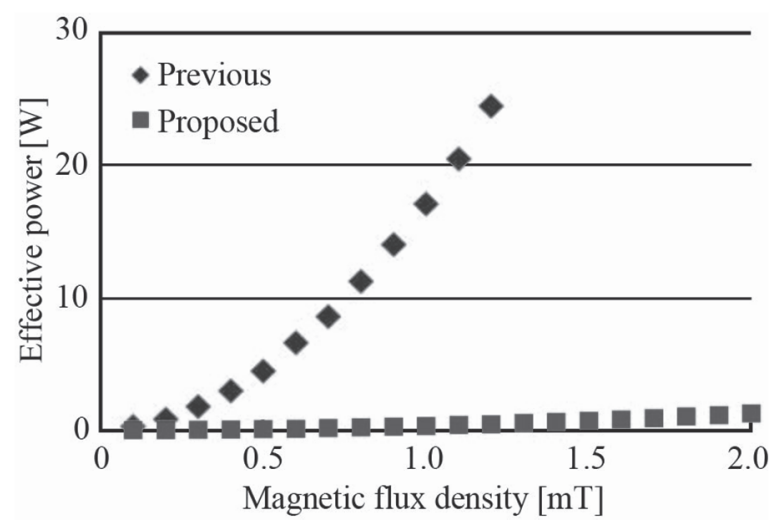

(a) DC

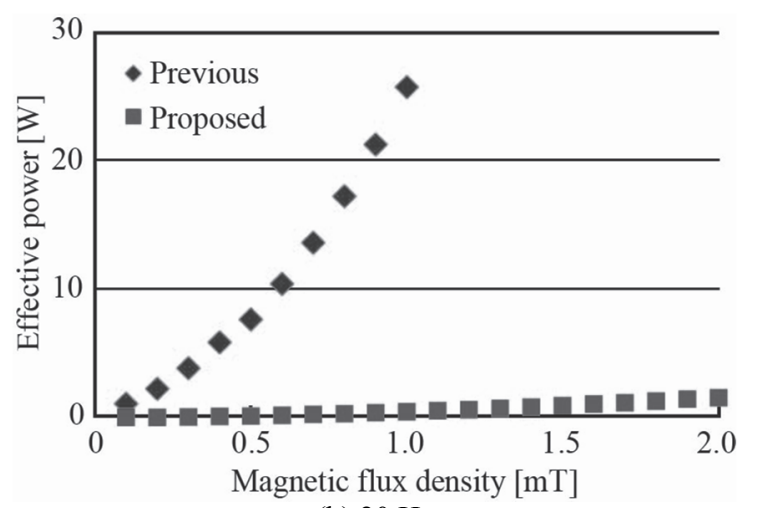

(b) $20 \mathrm{~Hz}$

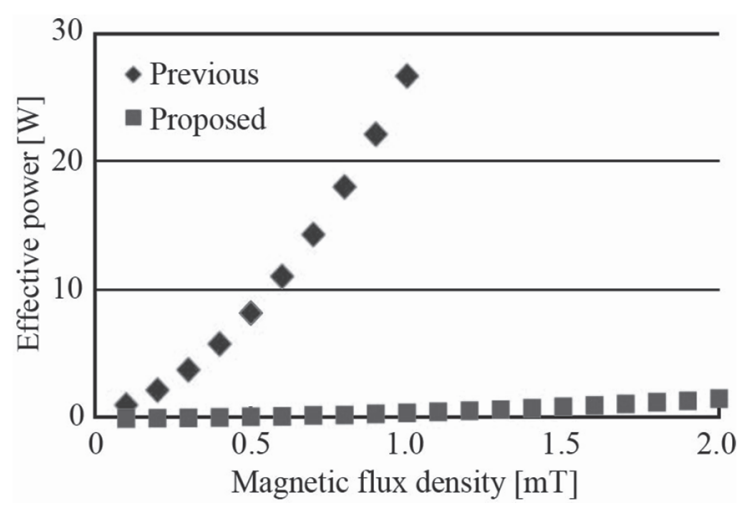

(c) $200 \mathrm{~Hz}$

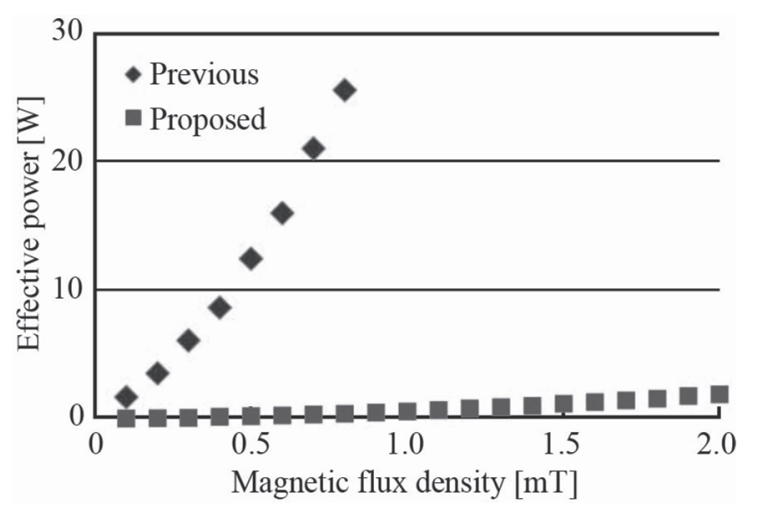

(d) $2 \mathrm{kHz}$

Fig.9 The relationship between the magnetic flux density and the effective power
Table 3 Reducing rate of the effective power

\begin{tabular}{c|c}
\hline \hline & Reducing rate [\%] \\
\hline $\mathrm{DC}$ & $97.4 \pm 0.2$ \\
\hline $20 \mathrm{~Hz}$ & $97.8 \pm 0.4$ \\
\hline $200 \mathrm{~Hz}$ & $97.9 \pm 0.4$ \\
\hline $2 \mathrm{kHz}$ & $98.4 \pm 0.3$ \\
\hline
\end{tabular}

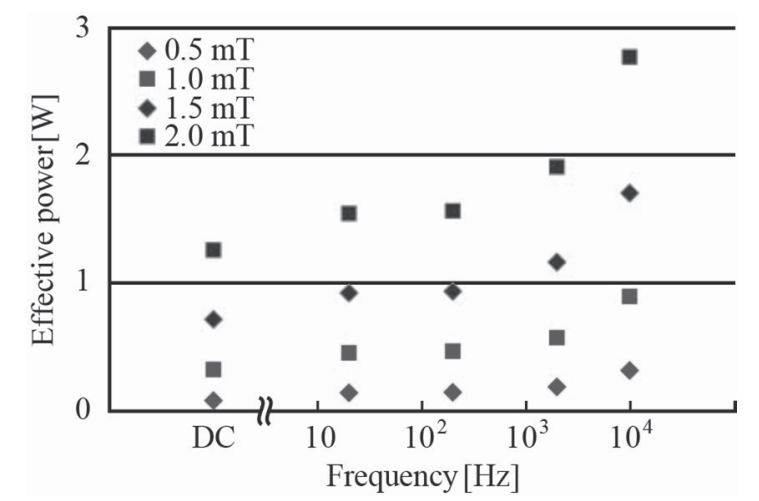

Fig.10 The relationship between the magnetic flux density and the effective power (Propose)

\section{3 冷却速度·冷媒温度均一性の比較}

冷却特性として, コイルで磁場を印加しながら冷媒を冷却した 際の泠却速度と冷媒温度均一性を, 従来コイルと新コイルで比較 した.

Fig.11 冷却速度・冷媒温度均一性計測のセットアップを示す。 スターリング冷却機(ツインバード工業社 SC-UE15R) に設置した 凍結槽に, 冷媒として無水エタノールを入れ, 試料を設置した。 従来コイル使用時と新コイル使用時では凍結槽の径が異なるた め, 無水エタノールを従来コイル使用時は $160 \mathrm{~mL}$, 新コイルは $120 \mathrm{~mL}$ 使用し, 試料を浸漬させる深さを統一した. 試験管には, 過冷却凍結の影響による冷媒の温度変化を防ぐため, 試料の代 わりにシステムの泠却温度範囲内では凍結しない無水エタノール を $1 \mathrm{~mL}$ 入れた. 冷却速度の制御は測温抵抗体で計測した温度 を基に, コントローラ(CHINO 社; KP1000C)を用いて行った. 冷 却速度は, 測温抵抗体に輪ゴムで固定した $\mathrm{K}$ 熱電対で計測した 温度から算出した. 冷媒の上部と下部の温度差を解消するため に, 送液ポンプ(ヤマ科学工業社; 7520-40)を用いて $80 \mathrm{~mL} / \mathrm{min}$ で泠媒を底面付近から吸い上げ, 液面付近から放出して環流し た. しかし, 磁場印加時はコイルの発熱により冷媒温度が不均一 になる可能性がある. そこで, 凍結槽底面から $5 \mathrm{~mm}$ (冷媒下部) と $30 \mathrm{~mm}$ (冷媒上部)の位置に K 熱電対を設置して冷媒温度を 計測し, その温度差から泠媒温度均一性を評価した。磁場の印 加は, バイポーラ電源 $(\mathrm{nF}$ 社; $\mathrm{BP} 4610)$ から発生した電流を, コイ ルに流すことで行った．Table 4 に示す条件で磁場を印加しなが ら $-1{ }^{\circ} \mathrm{C} / \mathrm{min}$ の設定で 60 分間冷却した. 磁場周波数は, $0.1 \mathrm{mT}$ 以上の磁束密度を発生可能かつ発熱の指標となる有効電力が 最大となる周波数に設定し, 従来コイルでは $2 \mathrm{kHz}$, 新コイルでは 


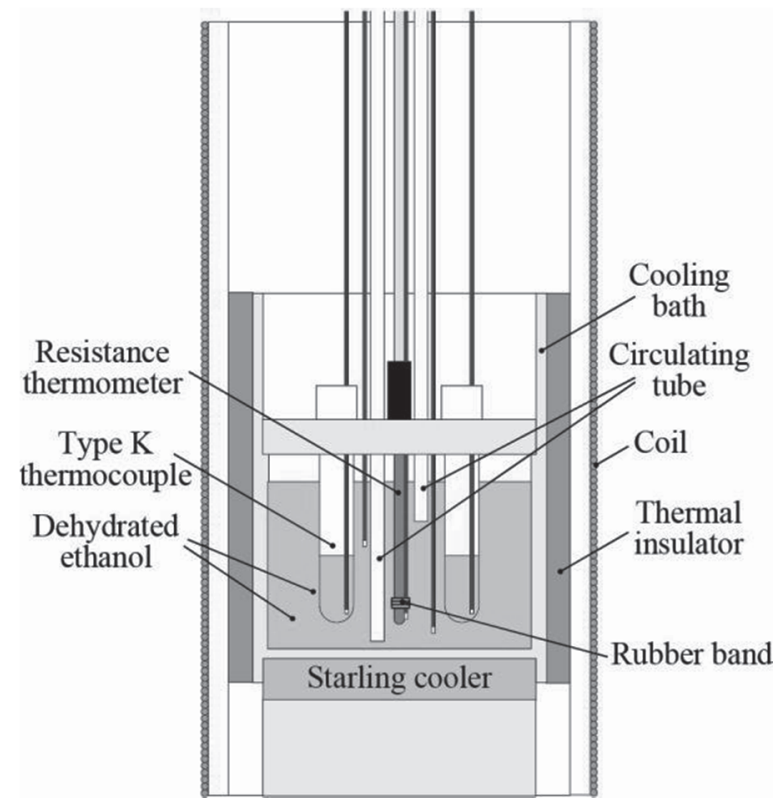

(a)Previous

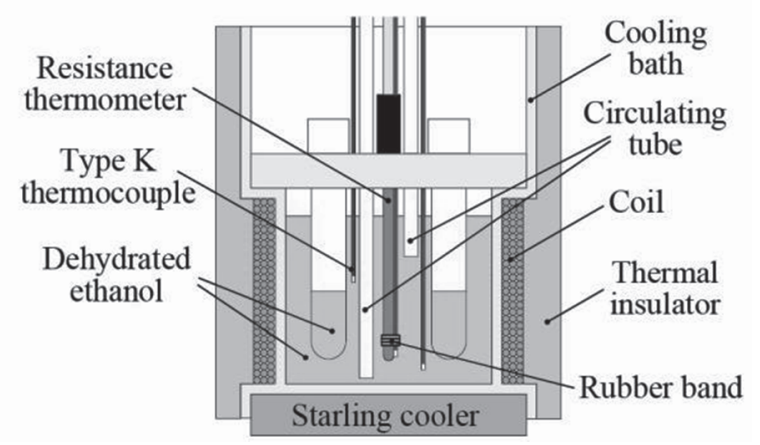

(b)Proposed

Fig.11 Cooling of cooling medium

Table 4 Magnetic field conditions in the experiment of cooling the cooling medium

\begin{tabular}{c|c}
\hline \hline & Magnetic flux density $[\mathrm{mT}]$ \\
\hline Previous $(2 \mathrm{kHz})$ & w/o, $0.3,0.5,0.8$ \\
\hline Proposed $(10 \mathrm{kHz})$ & w/o, $0.3,0.5,1.0,1.5,2.0$ \\
\hline
\end{tabular}

$10 \mathrm{kHz}$ とした.

Fig.12 に冷却速度の時間変化を示す. 従来コイル使用時は磁 場なし, $0.3 \mathrm{mT}$ 印加時に冷却速度が一定值に収束しつつあるの に対し, $0.5 \mathrm{mT}, 0.8 \mathrm{mT}$ 印加時に 50 分付近から冷却速度が低下 した. 一方で新コイル使用時は, 全ての磁束密度において冷却 速度が一定值に収束した。

Fig.13 に冷媒温度差の時間変化を示す. 従来コイル使用時は $0.5 \mathrm{mT}, 0.8 \mathrm{mT}$ 印加時に冷媒上下部の温度差が時間の経過に つれて拡大した. 一方で新コイル使用時は, 全ての磁束密度で 冷媒上下部の温度差を $1^{\circ} \mathrm{C}$ 以内に抑えた.

従来コイル使用時に冷却速度の時間応答がばらつき, 冷媒温 度差が拡大したのは, コイルの発熱量が冷却機の限界吸熱量を

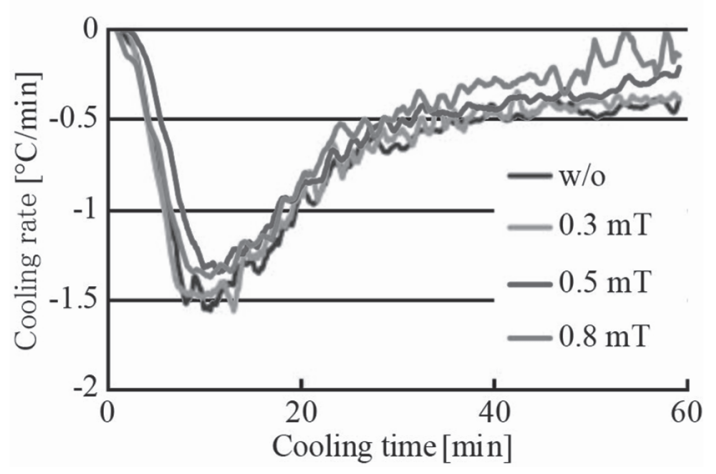

(a) Previous

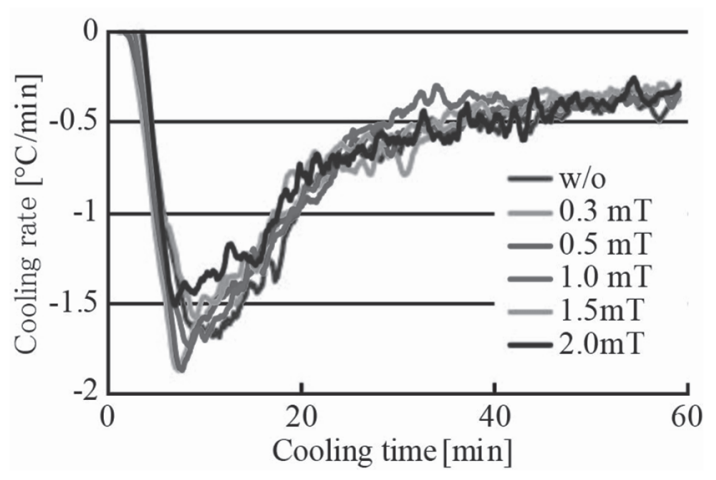

(b) Proposed

Fig.12 Time response of the cooling rate

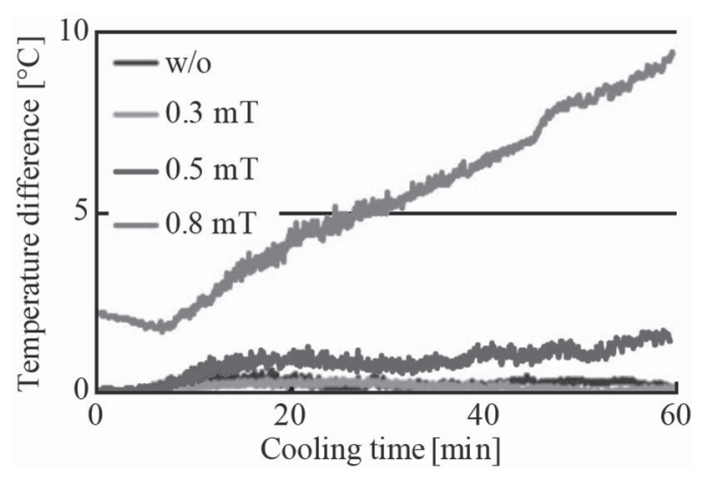

(a) Previous

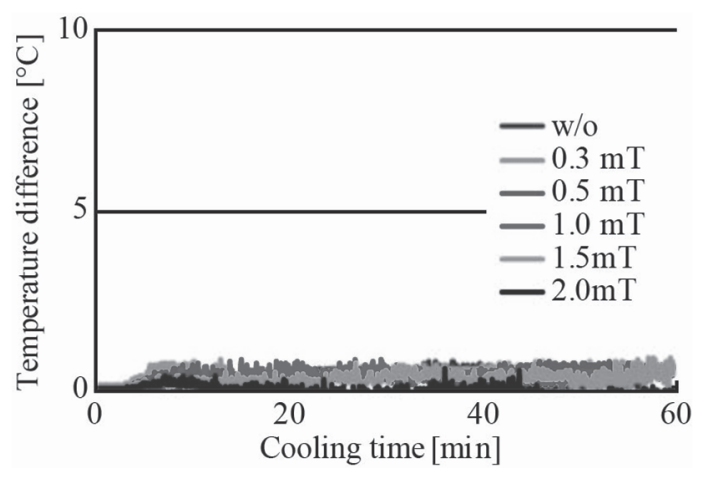

(b) Proposed

Fig.13 Time response of the temperature difference 
上回ったからであると考えられる. 新コイル使用時に冷却速度の 時間応答が均一で, 冷媒温度差が解消されたのは, コイルの発 熱量が下がり，またコイル自体も冷却できる構造になっているた めコイルの発熱量が冷却機の限界吸熱量の範囲内に収まったか らだと考えられる.ただし, 新コイルにおいても冷却速度が設定し た值に到達しなかったのは, 環流する際に一度冷媒が凍結槽外 に出されて室温に晒され, 外気から熱を吸収するためと考えられ る. 今後, 冷媒を凍結槽から出さずに冷媒温度を均一化する方 法を検討する.

以上の結果より, 新コイルは冷却特性が均一な磁束密度の上 限が従来の $0.3 \mathrm{mT}$ から $2.0 \mathrm{mT}$ まで向上した.

\section{5. 生体組織を用いた磁場下過冷却凍結実験}

試作したコイルを用いて生体組織を磁場下で過冷却凍結し, 過冷度の磁場周波数・磁束密度依存性を評価した. 試料には 5 $\mathrm{mm}$ 角に切断したブタ卵巣切片を使用した.

Fig.14にブタ卵巣凍結の実験セットアップを示す.ブタ卵巣切 片には K 熱電対を固定し, 試験管内で生理食塩水に浸漬させた. 冷却速度は $-1{ }^{\circ} \mathrm{C} / \mathrm{min}$ に設定し, 環流速度は $80 \mathrm{~mL} / \mathrm{min}$ に設 定した. 磁場条件は DC, $20 \mathrm{~Hz}, 200 \mathrm{~Hz}, 2 \mathrm{kHz}, 10 \mathrm{kHz}$ の 種 類の磁場周波数に対して, 磁束密度が $0.5 \mathrm{mT}, 1.0 \mathrm{mT}, 1.5 \mathrm{mT}$, $2.0 \mathrm{mT}$ の 4 種類の 20 種類, および磁場なしの計 21 種に設定し, 各磁場条件で 20 個の試料を過冷却凍結した. ブタ卵巣切片の 過冷度を算出するにあたり, ブタ卵巣切片上部, ブタ卵巣切片下 部, 生理食塩水の温度を計測した. 過冷却解消直前の温度と過 冷却解消直後の温度との差を，ブタ卵巣切片上部とブタ卵巣 切片下部で算出し, 上部と下部の平均值をブタ卵巣切片の過 冷度とした。

Fig.15 に磁場周波数と過冷度の関係を示す. $1.0 \mathrm{mT}, 2.0 \mathrm{mT}$ 磁場印加時は全周波数で磁場なし時に比べて過冷度が増加し, $10 \mathrm{kHz}$ 時に最大となった. 一方で, $0.5 \mathrm{mT}, 1.5 \mathrm{mT}$ 磁場印加時 は全周波数で磁場なし時に比べて過冷度が減少し, $0.5 \mathrm{mT}$ 磁場 印加時は $20 \mathrm{~Hz}, 1.5 \mathrm{mT}$ 磁場印加時は $200 \mathrm{~Hz}$ で過冷度が最小と なった.

Fig.16 に磁束密度と過冷度の関係を示す. 全磁場周波数にお いて $1.0 \mathrm{mT}, 2.0 \mathrm{mT}$ 磁場印加時に磁場なし時に比べ過冷度の

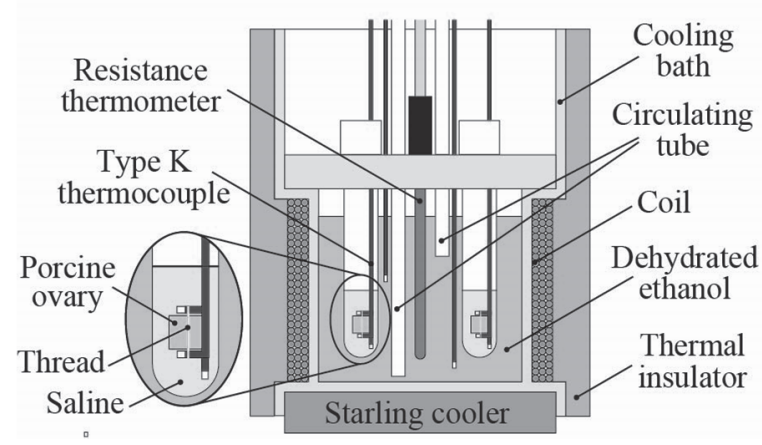

Fig.14 Experimental setup of freezing the porcine liver
平均值が増加し, $1.0 \mathrm{mT}$ 磁場印加時に比べ $2.0 \mathrm{mT}$ 磁場印加時 の方が増加量は大きかった. 一方, 全磁場周波数において 0.5 $\mathrm{mT}, 1.5 \mathrm{mT}$ 磁場印加時に磁場なし時に比べ過冷度の平均值が 減少し, $1.5 \mathrm{mT}$ 磁場印加時に比べ $0.5 \mathrm{mT}$ 磁場印加時の方が減 少量は大きかった。

また, それぞれの磁場条件における過冷度の平均值に対し, 有意水準 $5 \%$ のウェルチの $\mathrm{t}$ 検定による有意差検定を行った結 果, $1.0 \mathrm{mT}, 10 \mathrm{kHz}$ 時の過冷度と, $2.0 \mathrm{mT}, 10 \mathrm{kHz}$ 時の過冷度 は, 磁場なし時に比べ有意に増加していることを確認した。

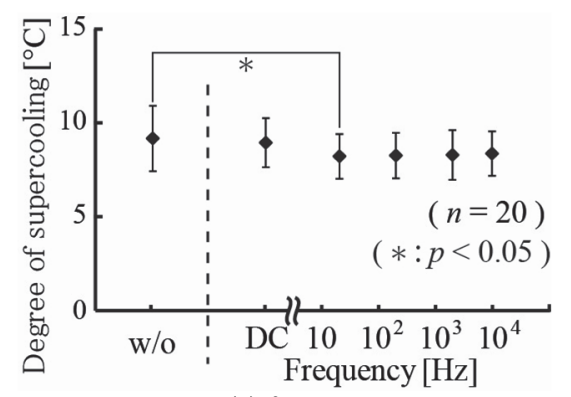

(a) $0.5 \mathrm{mT}$

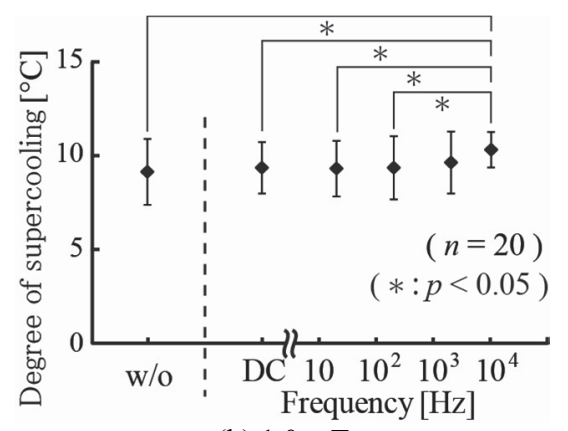

(b) $1.0 \mathrm{mT}$

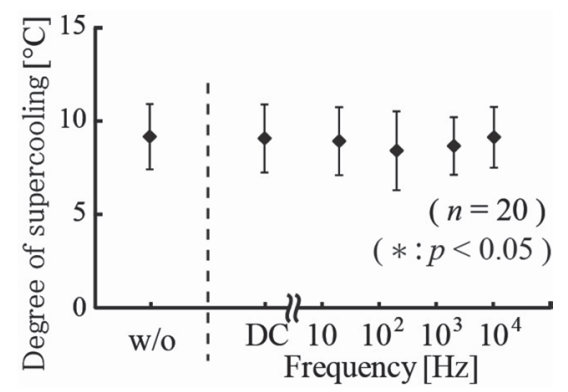

(c) $1.5 \mathrm{mT}$

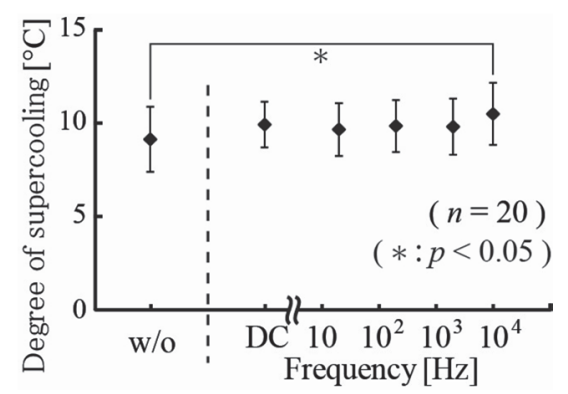

(d) $2.0 \mathrm{mT}$

Fig.15 The relationship between the frequency of applying magnetic field and the degree of supercooling $(\mathrm{w} / \mathrm{o}=$ without magnetic field $)$ 


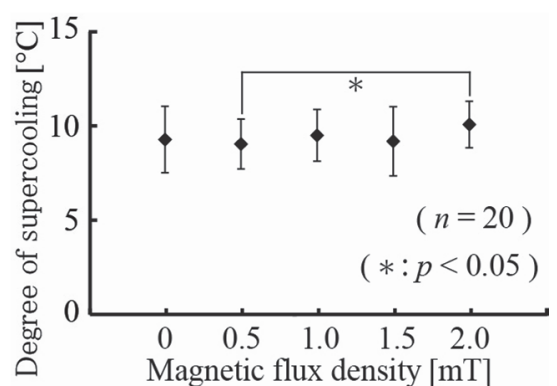

(a) DC

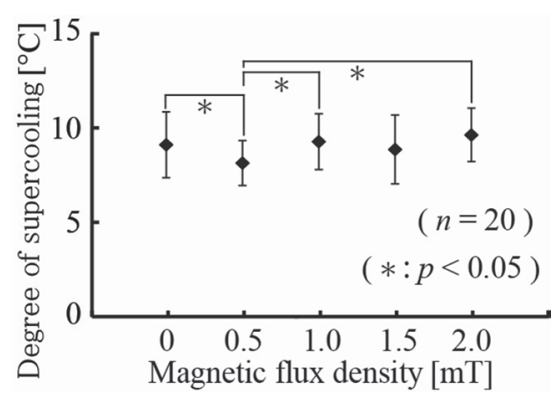

(b) $20 \mathrm{~Hz}$

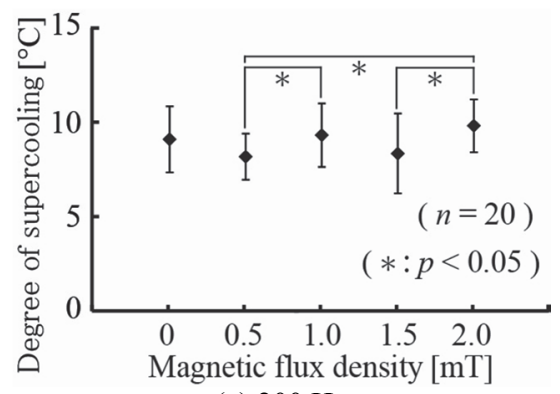

(c) $200 \mathrm{~Hz}$

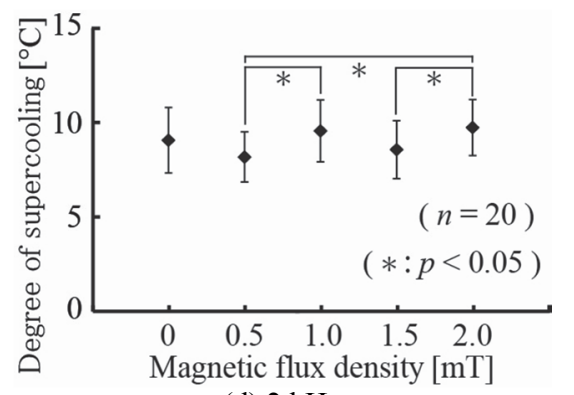

(d) $2 \mathrm{kHz}$

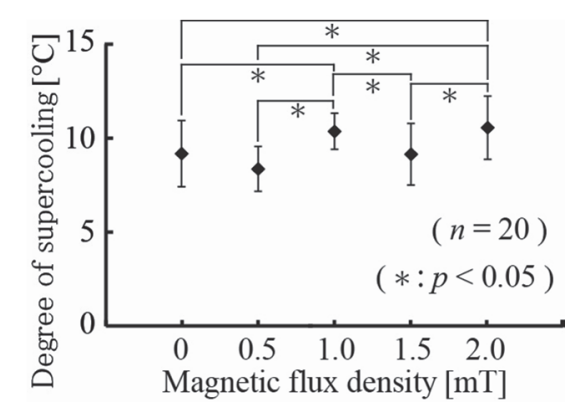

(e) $10 \mathrm{kHz}$

Fig.16 The relationship between the magnetic flux density of applying magnetic field and the degree of supercooling $(0 \mathrm{mT}=$ without magnetic field $)$
過冷度の磁場周波数・磁束密度依存性を評価した結果, 磁場な し時に比べて過冷度が有意に増加する磁場条件と, 有意に減少 する磁場条件が存在することを確認した. したがって, 過冷却凍 結において磁場を印加する際には, 適切な磁場条件を選定しな ければ過冷度が減少することもある. また過冷度に有意差の認め られた磁束密度の組み合わせの数は, DC 時に 1 通り, $20 \mathrm{~Hz}$, $200 \mathrm{~Hz}, 2 \mathrm{kHz}$ 時に 3 通り, $10 \mathrm{kHz}$ 時に 6 通りとなり, 磁場周波 数が大きいほど磁束密度の変化に対する影響が大きくなることを 確認した. 本研究で設定した磁場条件において, 過冷度は磁場 なし時の $9.1 \pm 1.7^{\circ} \mathrm{C}$ から $10 \mathrm{kHz}, 2.0 \mathrm{mT}$ 磁場印加時の $10.5 \pm$ $1.7{ }^{\circ} \mathrm{C}$ まで増加した. この過冷度の増加による細胞破壊の抑制 効果を確かめるために, 今後細胞観察による評価が必要となる. 磁場なし時の試作したコイルが発生できる磁場条件範囲内では, 磁束密度・磁場周波数を大きく設定することが過冷度の増加に繋 がるといらような単純な傾向は示されず, 今後は磁場条件と過冷 度との関連性について理論的に考察する必要がある.

\section{6. 結論}

本研究では, 生体組織の過冷却凍結における過冷度の磁場 周波数・磁束密度依存性の評価に向けて, 凍結槽一体型磁場印 加用コイルを試作した.

発生可能な磁束密度を計測した結果, 従来コイルは $2 \mathrm{kHz}$ に おいて $0.8 \mathrm{mT}$ 以上の磁場を発生できず, また $10 \mathrm{kHz}$ において $0.1 \mathrm{mT}$ 以上の磁場を発生できなかったが, 新コイルは DC, $20 \mathrm{~Hz}$, $200 \mathrm{~Hz}, 2 \mathrm{kHz}$ の全周波数で $2.0 \mathrm{mT}$ の磁場を発生した. 同じ磁束 密度を発生した際の有効電力を評価した結果, 新コイルは従来 コイルと比較して有効電力を DC 時に $97.4 \pm 0.2 \%, 20 \mathrm{~Hz}$ 時に $97.8 \pm 0.4 \%, 200 \mathrm{~Hz}$ 時に $97.9 \pm 0.4 \%, 2 \mathrm{kHz}$ 時に $98.4 \pm 0.3 \%$ 低減した. 冷却速度・冷媒温度均一性を評価した結果, 従来コイ ルは $0.5 \mathrm{mT}$ 以上の磁束密度で冷却速度の時間応答にばらつき が生じたが, 新コイルは $2.0 \mathrm{mT}$ まで時間応答が均一であった. ま た, 従来コイルは $0.5 \mathrm{mT}$ 以上の磁束密度において, 冷媒上下で $1^{\circ} \mathrm{C}$ を超える温度差が生じたが, 新コイルは $2.0 \mathrm{mT}$ まで $1{ }^{\circ} \mathrm{C}$ 以 内に抑えた.このように凍結槽一体型磁場印加用コイルは過冷 度の計測が可能な磁場周波数の最大值を従来の $2 \mathrm{kHz}$ から 10 $\mathrm{kHz}$ まで拡大し, 磁束密度の最大值を $0.3 \mathrm{mT}$ から $2.0 \mathrm{mT}$ まで拡 大した.

凍結槽一体型磁場印加用コイルを用いてブタ卵巣切片を磁場 下過冷却凍結した結果, 計測した過冷度は全磁束密度において $1.0 \mathrm{mT}, 2.0 \mathrm{mT}$ 磁場印加時に磁場なし時に比べて増加し, 0.5 $\mathrm{mT}, 1.5 \mathrm{mT}$ 磁場印加時に磁場なし時に比べて減少した. 過冷度 が最大となった磁場条件は $10 \mathrm{kHz}, 2.0 \mathrm{mT}$ で, 磁場なし時の 9.1 $\pm 1.7^{\circ} \mathrm{C}$ から $10.5 \pm 1.7^{\circ} \mathrm{C}$ まで増加した。

本研究の結果, 凍結槽一体型磁場印加用コイルの開発により 磁場下過冷却凍結時の磁場周波数・磁束密度範囲を拡大できる ことを確認した. また, 拡大された磁場周波数・磁束密度範囲内 において, ブタ卵巣切片の過冷度が増減することが確認され, 過 冷度の増加には適切な磁場周波数・磁束密度の設定が必要で あることが示された。 


\section{謝辞}

本研究の一部は, JSPS 科学研究費補助金 22240061, 及び私 立大学戦略的研究基盤形成支援事業 S1512001 の助成を受けた ものである.

\section{参考文献}

1）Kanit S, 中川毅史，野口修平，三原誠，小児がん男児の妊 孕性温存〜超微小血管外科技術を用いた精巣移植・精巣凍 結の可能性〜. Academic Collaborations for Sick Children 2009; 1(1): 16-19.

2) Ong WC, 中川毅史, 野口修平, 三原誠, 超微小血管外科技 術応用による血管柄付卵巣移植. Academic Collaborations for Sick Children 2009; 1(1): 4-7.

3) 藤川清三, 細胞内水晶形成による生体膜の障害. 凍結及び 乾燥研究会会誌 1978; 24: 31-33.

4) Whittingham DG, Leibo SP, Mazur P, Survival of mouse embryos frozen to -196 degrees and -269 degrees C. Science 1972; 178(4059): 411-414.

5) Donnez J, et al, Livebirth after orthotopic transplantation of cryopreserved ovarian tissue. Lancet 2004; 364(9443): 14051410.

6) $\mathrm{Ma} \mathrm{XH}$, et al, Slow-freezing cryopreservation of neural stem cell spheres with different diameters. Cryobiology 2010; 60(2): 184191.

7) Rall WF, Fahy GM, Ice-free cryopreservation of mouse embryos at -196 degrees $C$ by vitrification. Nature $1985 ; 313(6003)$ : 573-575.

8) Ishijima $T$, et al, Cryopreservation of canine ovaries by vitrification. J Reprod Dev 2006; 52(2): 293-299.

9) Moon JH, et al, Successful vitrification of human amnionderived mesenchymal stem cells. Hum Reprod 2008; 23(8): 1760-1770.

10) Wusteman M, Robinson M, Pegg D, Vitrification of large tissues with dielectric warming: biological problems and some approaches to their solution. Cryobiology 2004; 48(2): 179-189.

11) Liebermann J, Dietl J, Vanderzwalmen P, Tucker M.J, Recent developments in human oocyte, embryo and blastocyst vitrification: Where are we now? Reprod Biomed Online 2003; 7(6): 623-633.

12) 藤澤亮介，山下紘正，正宗賢，中川毅史，三原誠，土肥健 純, 組織凍結保存装置における過冷却に関寸る基礎的研究. Organ Biology 2010; 17(2): 190.

13) 林田貴之, 三原誠, 正宗賢, 桑名健太, 土肥健純, 交流磁 場下過冷却現象による臟器・生体組織凍結保存装置開発及 び基礎評価. 生体医工学 2011; 49(1): 166.(O2-13-2)

14) 守屋拓朗, 桑名健太, 正宗賢, 土肥健純, 過冷却凍結によ る生体組織凍結における冷媒の還流の効果の検証. Organ Biology 2012; 19(2): 206.

15) 小林りか, 兼坂尚宏, 渡辺学, 鈴木徹, 食品凍結時の過冷
却現象が氷結晶の形態およびドリップロスに及ぼす影響. 日 本冷凍空調学会論文集 2014; 31(3): 297-303.

16) 新野豊太郎 他, 磁場による過冷却現象を利用した卵巣の凍 結保存に関する研究. Journal of Japan Society of Computer Aided Surgery 2009; 11(3): 226-227.

17) 前川幸一郎, 荒井聰明, 送配電 新訂版. 東京: 東京電機大 学出版局, 1987.

18) 宇野辛一, 磯部直吉, 交流回路. 東京: 東京電機大学出版 局, 1991. 